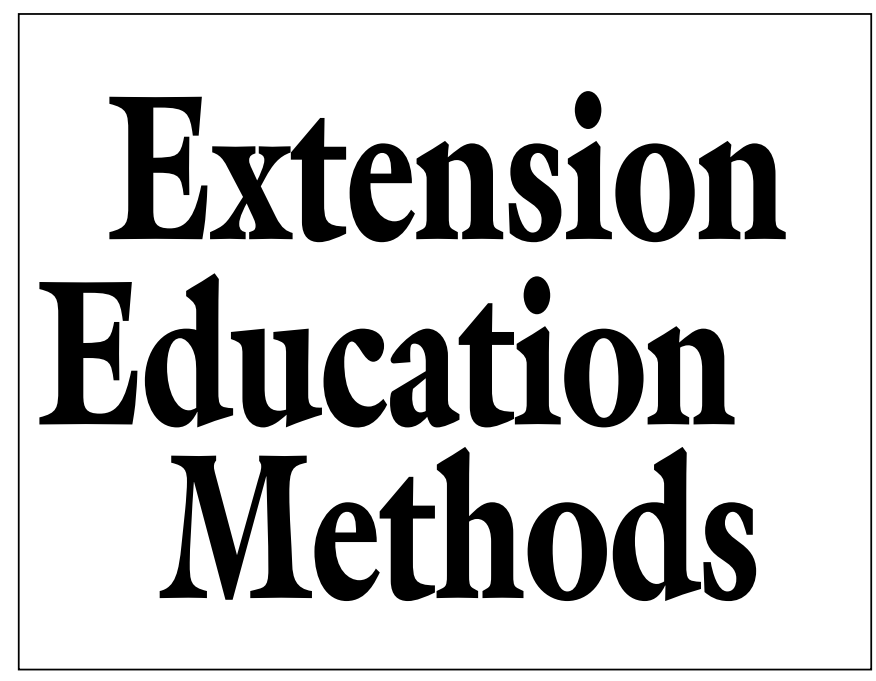

\section{Online Learning Equals Traditional Classroom Training for Master Gardeners}

\author{
Karen J. Jeannette ${ }^{l}$ and \\ Mary Hockenberry Meyer ${ }^{2}$
}

Additional InDEX wORDs. Internet, distance education, technology, discussion list, chat room, e-mail, extension teaching

\begin{abstract}
Summary. The effectiveness of Internet or online training was compared to traditional classroom training in the Master Gardener Core Course/Horticulture 1003 at the University of Minnesota, St. Paul. Overall horticultural knowledge was significantly greater for both groups in posttest results, and there was no significant difference in horticultural knowledge between the two groups. Online learners did not perceive the lack of instructor face-to-face interaction to be as important as did classroom participants. Online learners also placed a greater value on flexibility of class time and no commuting. Both groups spent approximately 75 hours on the class. However, $20 \%$ of classroom participants' time was commuting. Online training was an effective method for teaching Master Gardeners in this study.
\end{abstract}

\footnotetext{
O ince inception in 1977, the University of Minne$S$ sota Extension Service Master Gardener (MG) program has trained over 4,500 people using a 48 -h traditional classroom lecture series, or core course, provided

305 Alderman Hall, Department of Horticultural Science, University of Minnesota, St. Paul, MN 55108 .

This research has been supported in whole or in part by the Minnesota Agricultural Experiment Station.

${ }^{1}$ Former graduate student

${ }^{2}$ Associate professor.
}

by university faculty. The core course has also been taught as Horticulture 1003 at the University of Minnesota since 1999. Today, over 2,300 MGs are actively volunteering in Minnesota providing horticultural education to the public (Meyer and Hancheck, 1997). The current demand for MG training is high, but providing consistent, high quality training throughout the state can be expensive, time-consuming, and inefficient. Each year program administrators attempt to reach as many people as possible by selecting different training locations throughout the state.

By 1996, expanded Internet access across Minnesota made the possibility of developing an online class for MG training a promising idea. Traditionally, the majority of MGs tend to be over 40 years old, well educated, and highly motivated (Rohs and Westerfield, 1996; Schrock et al., 1999), characteristics of successful distance education participants (Bernt and Bugbee, 1993; Schlosser and Anderson, 1994; Wilkes and Burnham, 1991).

Stack (1997), and Warmond and Schrock (1999) found MG training via interactive television (ITV) to be just as effective as traditional classroom learning. Egan et al. (1991) reported that students in learning groups felt their learning experience via television was a real class even though their instructor was not physically present. Distance education using interactive media requires that the curriculum be well-planned and task-oriented, with ample opportunities for students to receive feedback to acknowledge personal success (Verduin and Clark, 1991). Distance education is further enhanced when a realistic classroom atmosphere is emulated by fully exploiting the interactive nature of the media, and by emphasizing teacher-student and student-student interactions (Batey and Cowell, 1986; Moore et al., 1990). Lippert et al. (2000) reported that $55 \%$ of extension agents who were offered Internet in-service training thought it provided a learning experience as effective as a face-to-face class.

Because the Internet is a new form of distance education, we wanted to determine if students could have a quality learning experience in a totally online class. The objectives of this study were to determine if online students learned just as much as classroom students; to measure their level of satisfaction with online learning; and to determine the appropriateness of online training for MGs.

\section{Materials and methods}

In 1996, the University of Minnesota MG Core Course was developed into 12 Internet modules, each with a list of objectives and tasks for students to complete. A sample of one module, Living with Wildlife, is shown in Fig. 1. In 1998 , the course was moved to a software program, WebCT 1.3 (WebCT, Inc., Lynnfield, Mass.).

In 2000, classroom MG training sessions were offered in Brainerd, Litchfield, and Rochester, Minn. and online (Table 1). In most cases, both online and classroom students were taught by the same instructors. Students in both classes received the same textbook and binder of extension publications. The classroom course consisted of $48 \mathrm{~h}$ of faceto-face lectures on 12 topics over 4-5 weeks. The online class consisted of 12 modules on the same topics requiring students to complete a list of assigned tasks (Fig. 1). One or two modules were assigned per week over 10 weeks for the online class, however students worked at their own pace, spending more or less time on topics of their choice. 


\section{¿ Master Gardener}

Hort 1003

Living with Wildlife

\section{Tasks}

1. Read the section on Living with Wildlife in the Core Course text and binder of Extension publications.

2. Review the Living with Wildlife slides.

3. Visit the following sites and submit your answers to the questions using the online assignment form.

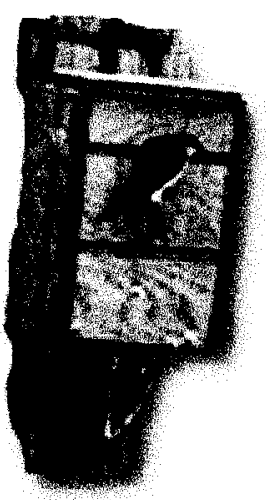

Visit this Ohio State Extension Service Factsheet about Controlling Rabbits in the Landscape.

- Which is the BEST way to control rabbits?
a. Moth balls and dial soap
b. Have-a-heart traps
c. Protective netting over top of plants
d. Habitat modification and exclusion techniques

The Minnesota DNR is always a good source to turn to for current information regarding wildlife. Take a look at the nuisance animal section of the MN DNR site. Pay special attention to the following links: "Taking a Nuisance Animal" and "Woodchucks", then answer the following questions.

- A nuisance animal normally protected by $\mathrm{MN}$ statute can be taken without license or permit if they are doing damage and if a conservation officer is called within 24 hours of the "taking".
a. true
b. false

- Which of the following methods is NOT legal for controlling woodchucks?
a. live trapping
b. poisons
c. shooting or hunting where permissible by law
d. none of the above

The Deer Damage and Control site at the University of Connecticut is a good resource for understanding the life history and habits of deer even though this site deals with a different U.S. region. It discusses many different ways to attempt to prevent deer from eating your favorite plants. Rhode Island's Sustainable Plants site lists plants deer do not like. At the link, scroll down to Appendix 2 then click on the list of Deer Resistant Plants. 
Fig. 1 (continued). Living with wildlife, an example of one module of the 2000 Minnesota Master Gardener Core Course.

- Which is the BEST long term way to control deer?
a. Moth balls and dial soap
b. Predator manure scattered around plants
c. Protective netting over top of plants
d. Habitat modification and exclusion techniques

Northwest Gardening, a gardening television series out of Oregon State University has a Sights and Sounds page that includes a video clip. The video clip is about deer damage. See the instructions for downloading the clip and then rate your experience with this clip in the online assignment form.

\section{Instructions for downloading clip}

Your browser should prompt you to download QuickTime(computer video software) if you do not already have it on your computer. Once you have found the sights and sounds page, scroll down and click on video clip \#103 so you can see the video. Depending on the speed of your modem, it may take awhile to download. You may want to read part of the core course text book while your waiting.

- Please rate this method of online learning by choosing 1 answer that best describes how you feel. If you choose the last answer (other), please email the TA and mention why you chose this.

a. I liked watching the clip

b. I liked watching the clip and would like to see more video clips throughout this course.

c. I watched, but the tech problems interfered with learning. Couldn't hear it or see it, poor quality.

d. I was unable to watch the video, don't know why.

e. other

Another streaming video clip provided by the University of Wisconsin, called Backyard Wildlife, talks about how you can prevent bird damage on your tree fruits.

\section{Instructions for downloading clip}

You'll need to have RealPlayer installed on your computer in order to play this clip.

Once you click on the bird damage link, step 1 will direct you to download the software if you do not have it already. You will want to download the "RealPlayer Basic" (the free version of RealPlayer). If you already have RealPlayer on your computer, go directly to Step 2. Start Streaming and click on the link, Birdtree.

- Please rate this method of online learning (again) by choosing 1 answer that best describes how you feel. If you choose the last answer (other), please email the TA and mention why you chose this.

a. I liked watching the clip

b. I liked watching the clip and would like to see more video clips throughout this course.

c. I watched, but the tech problems interfered with learning. Couldn't hear it or see it, poor quality.

d. I was unable to watch the video, don't know why. 


$$
\text { e. other }
$$

The University of Nebraska has published a large three ring binder with wildlife information. Many county Extension offices have this publication and Master Gardeners should become familiar with it. View some of these publications online at the University of Nebraska Extension Site. Many of these publications are great resources and are similar to the ones in your maroon binder.

- Which of the following about skunks is NOT true:

a. skunks may leave small holes in the ground where they've fed

b. skunks are nocturnal

c. skunks feed only on plant material

d. skunks can carry rabies

\section{Other useful wildlife resources}

The Extension Forestry pages from North Carolina State University contain a wealth of information on wildlife management. Enter on the glossary page and review these terms. Twenty-five other publications about the most common types of wildlife are listed at the end of the glossary. This site is concerned with increasing wildlife--not limiting it. In the case of hummingbirds and butterflies, most people are happy to see these, but no so for the deer and rabbits!! This is a good resource for further information.

This Minnesota Extension site provides information for planning for wildlife, managing wildlife, and enhancing wildlife. Visit the Managing Your Land for Wildlife site.

r. If possible, watch the University of Wisconsin Extension Service video "Backyard Wildlife". It is a good resource for additional training for this online class. Contact your county Extension office to borrow the video.

i. Participate in the email discussion this week.

\section{彭}

i. Take the Living with Wildlife Quiz

'. Fill out the Living with Wildlife Feedback Form.

(C) 2000, Regents of the University of Minnesota and the Department of Horticultural Science. All rights reserved.

\section{DA}

Table 1. Location and number of surveys used to measure learning in the 2000 Minnesota Master Gardener Core Course.

\begin{tabular}{lccc}
\hline Location & $\begin{array}{c}\text { Surveys } \\
\text { distributed } \\
\text { (no.) }\end{array}$ & $\begin{array}{c}\text { Surveys } \\
\text { completed } \\
\text { (no.) }\end{array}$ & $\begin{array}{c}\text { Surveys } \\
\text { completed } \\
\text { (\%) }\end{array}$ \\
\hline Brainerd & 30 & 25 & 83 \\
Litchfield & 26 & 23 & 88 \\
Rochester & 18 & 15 & 83 \\
Online & 67 & 54 & 81 \\
Total & 141 & 117 & 84 \\
\hline
\end{tabular}

An email discussion list, Mailman (Mailman Software, Boston, Mass.) where email messages are posted for a group at one address was the main form of communication for the online course. The weekly module instructors facilitated discussions by posting questions for students to respond using the email discussion list. The online class placed emphasis on the instructor as a facilitator rather than a lecturer. Additionally, a weekly voluntary chat room, an electronic space that allows for synchronous group communication, provided additional opportunities for group discussion.

To measure learning, all online students and a random 
sample of an equivalent number of classroom students were given a closed book pre- and posttest consisting of 30 horticulture questions. Students in the online class received their pretest and posttest by mail and were asked to return the tests as soon as possible, or within one week. Classroom students were asked to complete the pretest the first day of class and the posttest during the last day of class.

Additional questions, modified from Ward and Newlands (1996), determined learning preferences, advantages and disadvantages of online and classroom learning, course satisfaction, student demographics, and amount of time spent on the course. Students were asked to rate the importance of certain advantages and disadvantages of both classes on a five-point Likert scale, with possible responses on a continuum from "not important" to "important." Scores were compiled and subjected to a one-way analysis of variance, (SPSS, 1998).

\section{Results and discussion}

One hundred-seventeen matching pre- and posttests were collected (Table 1 ). The age distribution in this study (Table 2) was consistent with other MG programs where the majority of students were age 40 years and over (Schrock et al., 1999; Rohs and Westerfield, 1996). Participants were highly educated, the largest proportion held college degrees: $53 \%$ and $62 \%$ of the classroom and online students respectively had bachelor or graduate degrees.

A significant gain from pretest to posttest scores resulted for both classes, indicating students learned horticulture (Table 3 ). There was no significant difference between groups mean pre- and posttest scores, indicated both groups' horticulture knowledge was initially similar and both groups learned a similar amount by the end of the course. Students in both classes had fairly high knowledge entering class, answering $58 \%$ or $61 \%$ of the horticulture questions correctly in the classroom and online, respectively.

Responses to specific questions reflected students difficulty in certain topics such as Question 6: the amount of sand, silt, and clay in a soil refers to. This question was more difficult for all students even after they received the training. Posttest scores indicated that students were still confused about this concept. These findings indicate clarification and reinforcement of soil texture and structure is needed in both classes. Other questions that varied significantly between online and the classroom are listed in Table 4.

Classroom students indicated that they spent an average of 9 to $12 \mathrm{~h}$ studying in addition to the $48 \mathrm{~h}$ of in-class time for an average total of $60 \mathrm{~h}$ over 4 weeks of class (Table 5 ). The online students indicated they spent an average of 70 to $80 \mathrm{~h}$ on the course over a 10 -week period. Additionally, $80 \%$ of classroom students and $85 \%$ of online students rated the workload of the course as being just right (data not shown).

Classroom students reported an average driving distance of 26 to 40 miles ( 41.8 to $64.4 \mathrm{~km}$ ), which required $1.25 \mathrm{~h}$ to $15 \mathrm{~h}$ for the entire course (Table 5). Interestingly, online students reported the average distance they would be willing to drive was also 26 to 40 miles. All activities combined, the average classroom student spent a total of 72 to $75 \mathrm{~h}$ commuting, attending class, and studying, whereas the average online student spent 70 to $80 \mathrm{~h}$ studying or working on the class. Forty-eight percent of online students spent 9 or more hours per week on the course, slightly above the class average (Table 6). Thus, online students reported spending $16.5 \mathrm{~h}$ or $22 \%$ more time on the course than classroom students.

The two groups responses to learning questions were significantly different from each other on the posttest (Table 7). Not surprisingly, online students tended to favor elements of an online class, and classroom students tended to favor traditional classroom learning elements.

When asked how important the advantage of a structured learning environment was in a face-to-face class, classroom students thought it was very important on both the pretest and posttest. Online students responded much differently, showing only a slight to moderate advantage on both the pretest and posttest results (Table 7).

When asked how important the advantage of face-toface contact with the instructor was, neither class denied that this was an important advantage in pretest data. By the posttest, however, classroom students thought face-to-face contact to be a significantly more important advantage,

Table 2. Demographic information of online and classroom participants in the 2000 Minnesota Master Gardener Core Course.

\begin{tabular}{|c|c|c|c|c|}
\hline \multirow{3}{*}{$\begin{array}{l}\text { Demographic } \\
\text { information }\end{array}$} & \multicolumn{4}{|c|}{ Responding participants $(\%)^{\mathrm{z}}$} \\
\hline & \multicolumn{4}{|c|}{ Location } \\
\hline & Brainerd & Litchfield & Rochester & Online \\
\hline \multicolumn{5}{|l|}{ Gender } \\
\hline Female & 68 & 70 & 80 & 81 \\
\hline Male & 24 & 13 & 13 & 15 \\
\hline $26-35$ & 4 & 13 & 7 & 11 \\
\hline $36-45$ & 16 & 17 & 33 & 30 \\
\hline $46-60$ & 56 & 52 & 27 & 46 \\
\hline $60+$ & 16 & 13 & 27 & 5 \\
\hline \multicolumn{5}{|l|}{ Education level completed } \\
\hline High school diploma & 12 & 13 & 20 & 17 \\
\hline
\end{tabular}

${ }^{\mathrm{z} N o t}$ all participants answered all questions. 
Table 3. Mean percentage of correct responses for horticulture questions from classroom and online students in the 2000 Minnesota Master Gardener Core Course.

\begin{tabular}{|c|c|c|c|c|}
\hline \multirow[b]{3}{*}{ Question } & \multicolumn{4}{|c|}{ Correct responses (\%) } \\
\hline & \multicolumn{2}{|c|}{ Pretest } & \multicolumn{2}{|c|}{ Posttest } \\
\hline & Slassroom & Online & Classroom & Online \\
\hline Food manufactured in the leaves moves to the roots through the & 24 & 33 & 65 & 59 \\
\hline A perfect flower has & 71 & 80 & 86 & 96 \\
\hline The metabolic process where a plant uses carbohydrates produced during & & & & \\
\hline photosynthesis for growth is known as & 13 & 20 & 64 & 67 \\
\hline Working garden soils when very wet destroys soil & 49 & 50 & 67 & 76 \\
\hline Most soil nutrients needed for plant growth are most available in a soil range of & 83 & 76 & 97 & 100 \\
\hline The amount of sand, silt, and clay in a soil refers to & 65 & 48 & 27 & 26 \\
\hline $\begin{array}{l}\text { Failure of young fruit trees to bear fruit is related to a particular growth stage } \\
\text { known as juvenility }\end{array}$ & 60 & 54 & $81^{* \star}$ & $63^{* *}$ \\
\hline $\begin{array}{l}\text { Which of the following series of plants would be good for a rotation plan for } \\
\text { disease reduction? }\end{array}$ & $57^{* *}$ & $82^{\star *}$ & 84 & 96 \\
\hline The purpose of mulch in the vegetable garden is to & 89 & 82 & 98 & 98 \\
\hline Insects with piercing -sucking mouth parts cause damage by & 84 & 83 & 94 & 87 \\
\hline The best time to control a caterpillar defoliator is & 22 & 30 & 60 & 33 \\
\hline What do springtails, fungus gnats, and slugs have in common? & $44^{* *}$ & $70^{\star *}$ & 71 & 87 \\
\hline Powdery mildews are easy to recognize by & 94 & 89 & 100 & 96 \\
\hline Viral diseases are spread primarily by & 27 & 32 & 38 & 35 \\
\hline To help prevent oak wilt disease in Minnesota DO NOT PRUNE oaks in & 48 & 43 & 83 & 83 \\
\hline $\begin{array}{l}\text { If a homeowner decides on fertilizing their lawn once a year, which is the best time } \\
\text { to fertilize? }\end{array}$ & 44 & 52 & 76 & 80 \\
\hline Leaving lawn clippings after mowing can account for & 40 & 41 & $98^{* *}$ & $61^{* *}$ \\
\hline A person wishing to establish a lawn in a sunny area with low maintenance should select & ct 33 & 30 & 57 & 50 \\
\hline The MOST limiting factor in growing indoor plants in Minnesota is & 83 & 96 & 98 & 98 \\
\hline When is the best time to fertilize a houseplant? & 62 & 52 & 95 & 96 \\
\hline Annual and perennial flowers have different needs, such as & 81 & 83 & 86 & 85 \\
\hline Winter mulch should be applied & 52 & 43 & 76 & 72 \\
\hline Which should NOT be included for hardening annuals before planting into the garden? & 1? 56 & 57 & $14^{* *}$ & $70^{* *}$ \\
\hline The BEST way to reduce animal pest problems is to & 60 & 61 & 95 & 100 \\
\hline Moles primarily feed on & 16 & 24 & 64 & 69 \\
\hline The reentry statement on a pesticide label states how much time must pass before: & 38 & 44 & 89 & 98 \\
\hline You should read the pesticide label before you & 94 & 96 & 94 & 98 \\
\hline A good evergreen for hedges in Minnesota is & 83 & 80 & 89 & 87 \\
\hline Renewal pruning is accomplished for older or overgrown shrubs by & 73 & 72 & 86 & 85 \\
\hline $\begin{array}{l}\text { Shigo indicates that trees form four walls of barriers to disease entering around a wound. } \\
\text { Of all the walls, the last wall or barrier to form is the strongest disease barrier, but the } \\
\text { weakest structurally. }\end{array}$ & e & 57 & 67 & 67 \\
\hline Grand mean & $58 a^{z}$ & $61 \mathrm{a}$ & $79 \mathrm{~b}$ & $80 \mathrm{~b}$ \\
\hline
\end{tabular}

${ }^{\mathrm{z}}$ Grand mean followed by different letters are significant at $P=0.01$.

${ }^{* \star}$ Significant pretest or posttest responses at $P=0.01$.

Table 4. Horticulture questions with significantly different responses between classroom and online students in the 2000 Minnesota Master Gardener Core Course.

\begin{tabular}{|c|c|c|c|c|}
\hline \multirow[b]{3}{*}{ Question } & \multicolumn{4}{|c|}{ Correct responses (\%) } \\
\hline & \multicolumn{2}{|c|}{ Pretest } & \multicolumn{2}{|c|}{ Posttest } \\
\hline & Classroom & Online & Classroom & Online \\
\hline \multicolumn{5}{|l|}{ Failure of young fruit trees to bear fruit is related to a particular growth stage } \\
\hline known as juvenility. & 60 & 54 & $81^{\star *}$ & $63^{\star *}$ \\
\hline Which of the following series of plants would be good for a rotation plan for disease & & & & \\
\hline reduction? & $57^{* *}$ & $82^{* *}$ & 84 & 96 \\
\hline What do springtails, fungus gnats, and slugs have in common? & $44^{* *}$ & $70^{* *}$ & 71 & 87 \\
\hline Leaving lawn clippings after mowing can account for & 40 & 41 & $98^{* *}$ & $61^{* *}$ \\
\hline Which should NOT be included for hardening annuals before planting into the garden & en? 56 & 57 & $14^{* *}$ & $70^{\star \star}$ \\
\hline
\end{tabular}


Table 5. Amount of time spent on course activities in the 2000 Minnesota Master Gardener Core Course.

\begin{tabular}{lcc}
\hline & \multicolumn{2}{c}{ Mean time (h) } \\
\cline { 2 - 3 } Activity & Classroom participants & Online participants \\
\hline Driving & 15 & 0 \\
In class time & 48 & 0 \\
Studying & $9-12$ & $70-80$ \\
Total & $72-75$ & $70-80$ \\
\hline
\end{tabular}

Table 6. Weekly hours reported by students working on the 2000 online Minnesota Master Gardener Core Course.

\begin{tabular}{lc}
\hline Hours & $\begin{array}{c}\text { Responding } \\
\text { participants } \\
\mathbf{( \% )}\end{array}$ \\
\hline $2-4$ & 8.1 \\
$5-6$ & 13.5 \\
$7-8$ & 29.7 \\
$9-10$ & 16.2 \\
$11-12$ & 32.4 \\
$7-8$ & Overall mean \\
\hline
\end{tabular}

while the online students thought this contact to be significantly less important (Table 7).

When asked how important the advantages of having a greater choice of when to study and not having to drive or spend commuting time in an online class, the classroom students saw these as slight advantages on the pretest and the online students saw these as very important. By the posttest, classroom students rated these advantages as moderately important, indicating that they thought these time factors were more important advantages than they originally had thought. However, they still did not rate these advantages as highly as online students (Table 7).

Classroom students perceived the lack of flexibility and commuting as a minor disadvantage in the pretest and viewed this as more of a disadvantage by the posttest. Online students thought that these were moderately important disadvantages at the beginning and even more so on the posttest (Table 7). The issue of time and distance plays a role in how students perceive each type of class. Students who can take the classroom course find less advantages in taking the course online. Students that are constrained by time and distance issues find the online class a great opportunity and are more enthusiastic about taking the course online.

Classroom and online students did not perceive technical frustrations, such as hardware and software issues, as much of a problem. On the pretest, both the classroom and online students thought technical frustrations would be a moderately important disadvantage (Table 7). Surprisingly, the posttest showed that online students did not find this to be a bigger disadvantage, but classroom students, who had not even taken the course over the Internet did feel this would be more of a disadvantage, which may explain why they took the class in the traditional classroom in the first place. Ward and Newlands (1998) indicated students rated technical frustration as high. Technical frustrations that stem from dealing with the online content or system crashes are important issues that can distract student learning. The MG course has created several online hyperlinks that provide tools for aiding students in understanding technical aspects of the course and their computers.

On the pretest, both classroom and online students rated the loss of contact with the instructor in an online class as a slightly important disadvantage. The posttest revealed that classroom students increased their rating of loss of contact with the instructor as a greater disadvantage, while online students continued to perceive this disadvantage as only slightly important (Table 7). These differences suggest that classroom students thought the in class contact with the instructor was necessary for training, while the online students were able to learn with less instructor involvement.

Both groups rated "an alienating learning experience" of an online class, as a slightly important disadvantage on the pretest. However, the online students thought this was less

Table 7. Student perceptions of advantages and disadvantages of classroom and online instruction in the $2000 \mathrm{Minnesota}$ Master Gardener Core Course.

\begin{tabular}{|c|c|c|c|c|}
\hline \multirow[b]{3}{*}{ Question } & \multicolumn{4}{|c|}{ Mean perception ${ }^{\mathrm{z}}$} \\
\hline & \multicolumn{2}{|c|}{ Pretest } & \multicolumn{2}{|c|}{ Posttest } \\
\hline & Classroom & Online & Classroom & Online \\
\hline $\begin{array}{l}\text { Structured learning environment (where instructor/class provides the tempo } \\
\text { for assignments and tasks) }\end{array}$ & $3.8^{* *}$ & $3.0^{* *}$ & $4.2^{* *}$ & $2.6^{\star *}$ \\
\hline Face-to-face interaction with the instructor & 4.1 & 3.8 & $4.5^{* *}$ & $3.5^{\star *}$ \\
\hline No driving or commuting time & $3.0^{\star *}$ & $4.8^{\star \star}$ & $4.0^{\star \star}$ & $4.8^{* *}$ \\
\hline \multicolumn{5}{|l|}{ What disadvantages of a face-to-face class do you perceive as important? } \\
\hline Driving/commuting time to get to class & $2.7^{\star *}$ & $4.1^{\star *}$ & $3.0^{* *}$ & $4.2^{* *}$ \\
\hline Class time is not flexible & $2.8^{\star *}$ & $4.4^{* *}$ & $3.3^{\star *}$ & $4.6^{* *}$ \\
\hline \multicolumn{5}{|l|}{ What disadvantages of an Internet class do you perceive as important? } \\
\hline
\end{tabular}

${ }^{\mathrm{z}} l=$ not important to $5=$ very important.

${ }^{* *}$ Significantly different at $P=.01$. 
Table 8. Students satisfaction with online learning in the 2000 Minnesota Master Gardener Core Course.

Statement

Mean perception ${ }^{\mathrm{z}}$

The Internet can provide a learning experience as effective as face to face learning

4.14

The flexibility of learning time was a significant advantage

4.88

I would recommend this form of distance learning

4.76

I would take another Internet class

4.74

This training helped increase my skills on the Internet

4.36

I was comfortable with this method of learning

4.50

${ }^{\mathrm{z}}$ Based on 50 responses; $1=$ disagree, $5=$ agree.

of a disadvantage on the posttest, while the classroom students thought that taking a class online would be fairly alienating, and thus a large disadvantage (Table 7). Classroom students may have reacted this way because they really enjoyed the interaction they had with the instructors and thought an Internet class would not give them the same opportunity. The responses of online students may be interpreted in two ways. Even though learning online may have been perceived as an alienating learning experience, the students were not as concerned about being connected to the class as a community. Students may have preferred to do their work with little interruption. However, many online students reported they were able to network and form an online community. Students commented on how surprised they were that communication between with the instructors and other students seemed personable, despite the fact that they never had face-to-face contact. One student said, "I was quite concerned about trying to learn this way... It is still a little weird I guess, but I do feel that it is a lot more personal than I could have guessed.”

Online MG students were also positive on the advantage of being able to take the training and become a MG no matter how far they were from the training site. One student commented, "I can not tell you how wonderful it is to take the Internet class. Without this opportunity I wouldn't have been able to take the training!" In addition, others really enjoyed working on their own and were excited about using a new medium to research and learn about horticulture. They felt that taking the course this way provided them with improved technical research skills.

Overall student perceptions of the MG online class were favorable (Table 8). Wards and Newlands (1996) substituted one quarter of an undergraduate economics classroom lectures with online materials, and reported that students rated disadvantages of an online class, such as the loss of contact with the instructor, to be more important than in this study.

Eighty-nine percent of the online students ranked their satisfaction with email as good or very good (communication tool data not shown). Most students were familiar with this communication tool before the class began. Bonk and Cummings (1998) suggest that Web-based courses should establish a safe environment, while also using public and private forms of feedback. Email served as the primary method of private or personalized feedback for students. Therefore, the familiarity students have with using email combined with the opportunity for private instructor feedback seems to make satisfaction with using email quite high, especially when email messages are promptly answered.

All online students were subscribed to the online discussion list, but $11 \%$ never posted a message, leaving $89 \%$ who actively used the online discussion list. Sixty-five percent rated their satisfaction with this communication tool as good or very good. Complaints associated with the online discussion list were usually related to getting too many messages, similar to other reports (VanVranken and Cowgill, 1996). Some students felt that it was inappropriate to ask personal learning questions over the online discussion list, rather than sending a personal email to an instructor. However, other students felt that sharing questions was a valuable learning experience.

The chat room, the only source of synchronous communication, functioned at two different times each week, averaging 10 to 20 students in attendance per time. A taped log of the chat room was sent via email the following day to the entire class. Smaller chat groups tended to encourage everyone to participate. Students could ask any outstanding questions concerning the weekly units, and other related topics such as plant diagnostics, were also covered in the chat sessions. Eighty-seven percent of students said they had used the chat room at least once during the course and $63 \%$ rated their satisfaction with the use of this tool as good or very good. Large chat room groups resulted in fewer students actively initiated questions and responses. In an ITV course, Egan et al. (1991) reported students working in smaller learning groups felt there was a sense of community, were less likely to drop out, and that smaller groups stimulated active discussions. Other studies have found less student satisfaction with using chat rooms (Paparozzi and Williams, 2000).

Online students were required to actively access the course materials and search for responses in online site visits and reading the text. At the end of the course, several online students mentioned how confident they had become in finding reliable reference information over the web. Classroom students, however learned primarily by listening to lectures, which required less active participation.

\section{Conclusion}

The results of this study suggest that online learning can be just as effective as classroom learning for $\mathrm{MG}$ training. Internet distance education provides flexibility and convenience, two major advantages that learners rate as very important. What students learn appears to be based on how the information is organized, presented, and emphasized. Comparisons can be seen where students have similar pretest scores on a specific question, but have significantly different posttest scores. These findings stress that it is not necessarily the method used to deliver the information as the way in which material is organized, presented, and emphasized that creates an effective learning environment.

Bonk and Cummings (1998) propose that rather than 
distribute all information via lecture, instructors should use the vast resources available on the world wide web, which may be far richer in content than just using a textbook or lecture. They offer guidelines and suggestions for designing and teaching an online course including: using a facilitator rather than a lecturer; providing students immediate feedback on their assignments and quizzes, using public and private forms of feedback to establish a safe environment; and taking advantage of the wide-resources available on the world wide web, rather than simply posting lecture notes or text from a book.

An online class, with its versatility of information and communication tools, should allow students to capitalize on their individual strengths, while at the same time providing clear expectations and prompt task structuring (Bonk and Cummings, 1998; Nelson, 1998).

Our findings and those of Batey and Cowell (1986) indicate that self-motivated students appear to learn well through distance education. Wilkes and Burnham (1991) report satisfaction in using electronic education is likely to be attributed to external factors, such as time and energy for development and instruction, and clarity of information. If motivation is an essential key to learning and external factors are the key to satisfaction with a learner, then motivated students taking a well organized and appropriately designed class, should do well and find the experience satisfying whether in a classroom or online. Preliminary findings also show that participants trained online will volunteer in the community at a level similar to volunteers trained in the classroom.

The results of this study indicate classroom students are highly motivated to take the course in the classroom, and online students are highly motivated to take the course online. Students in both classes did equally well on the posttests and rated their satisfaction with their class as high, indicating that either method is appropriate for teaching MGs.

\section{Literature cited}

Batey, A. and R.N. Cowell. 1986. Distance education: An overview. N.W. Reg. Educ. Lab., Portland, Ore.

Bernt, F.L. and A.C. Bugbee. 1993. Study practices and attitudes related to academic success in a distance learning programme. Distance Educ. 14:97-112.

Bonk, C. J. and J.A. Cummings. 1998. A dozen recommendations for placing the student at the centre of web-based learning. Educ. Media Intl. 25:82-89.
Egan, M.W., J. Sebastian, and M.Welch. 1991. Effective television teaching: Perceptions of those who count most... distance learners. 17-20 Mar. Proc. Rural Educ. Symp., Nashville, Tenn.

Lippert, R., O. Plank, and R. Radhakrishna. 2000. Beyond perception: A pretest and posttest evaluation of a regional internet extension training. J. Ext. 38. 11 Nov. 2000. <http:// www.joe.org/joe/2000april/a2.html>.

Meyer, M.H. and A.M. Hancheck. 1997. Master Gardener training costs and payback in volunteer hours. Hort Technology 7:368370 .

Moore, M.G., M.M. Thompson, A.B. Quigley, G.C. Clark, and G.G. Goff. 1990. The effects of distance learning: A summary of literature. Amer. Ctr. Study Distance Educ., College of Educ, Pa. State Univ., Univ. Park.

Nelson, G. 1998. Internet/Web-based instruction and multiple intelligences. Educ. Media Intl. 35:90-94.

Paparozzi, E.T and K.A. Williams. 2000. Using chat rooms in a plant nutrition course: Bane or boon? HortTechnology 10:280282.

Rohs, F.R. and R.R. Westerfield. 1996. Factors influencing volunteering in the Master Gardener program. Hort Technology 6:281285 .

Schlosser, C.A. and M.I. Anderson. 1994. Distance education: A review of the literature. Iowa Distance Educ. Alliance, Iowa State Univ., Ames.

Schrock, D.S., M. Meyer, P. Ascher, and M. Snyder. 1999. Missouri Master Gardener demographics. J. Ext. 37. 4 Nov. 1999. <http://www.joe.org/joe/1999october/rb4.html>.

Statistical Packages for Social Sciences. 1997. SPSS 8.0 for Windows. Statistical Packages for Social Sciences, Chicago, Ill.

Stack, L.B. 1997. Interactive television delivers Master Gardener training effectively. HortTechnology 7:357-359.

VanVranken, R.W. and W.P. Cowgill. 1996. Using electronicmail discussion groups on the internet to enhance communication in specific commodity groups. HortTechnology 6:318-324.

Verduin, J.R. and T.A. Clark. 1991. Distance education: The foundations of effective practice. Jossey-Bass. San Francisco, Calif.

Ward, M. and D. Newlands. 1998. Use of the web in undergraduate teaching. Computers Educ. 31:171-184.

Warmond, M. and D. Schrock. 1999. Clientele perceptions of Master Gardener training delivered via interactive television versus face to face. Hort Technology 9:116-121.

Wilkes, W.C. and B.R. Burnham. 1991. Adult learner motivations and electronic distance education. Amer. J. Distance Educ. 5:4350 . 